\title{
CONSIDERATIONS ON THE LIMITS OF THE PRIVATE PROPERTY RIGHT AND ITS IMPLICATIONS IN THE CONCEPT OF URBAN RENEWAL \\ S. E. Ciudin - Colţa
}

\author{
Smărăndița - Elena Ciudin- Colţa \\ Faculty of Law, Comparative Private Law Department \\ "Alexandru Ioan Cuza" University of Iaşi, Romania \\ *Correspondence: Smărăndiţa- Elena Ciudin- Colţa, Alexandru Ioan Cuza University of Iaşi, 11 \\ Carol I St., Iaşi, Romania \\ E-mail: smarandaro@yahoo.com
}

\begin{abstract}
:
The purpose of our paper is to analyze the concept of "urban renewal", defined by the Wallonian code on land use planning, urban planning, patrimony and energy and by the provisions of the French laws as the phenomenon by means of which towns and cities evolve in order to face new community needs. Urban renewal is closely connected to servitudes and private property limits, to which we will refer in the light of the provisions of the New Civil Code of Romania.
\end{abstract}

Key words: urban renewal, private servitude, urban planning servitude, principle of non indemnification of urban planning servitude effects.

\section{Introduction}

Just like living organisms, cities seem to be in an incessant renewal process, which allows them to survive, despite the ever-changing nature of human activities. The concrete materialization of this transformation consists of hygienic conditions in buildings, access road development, etc. The analysis of the social trends and legal regulations on property rights, servitudes and property right limits throughout Europe is a real challenge. In response to heavy doctrine criticism, the New Romanian Civil Code made the due distinction between the legal limits of the property right and the actual servitudes.

\section{Private Servitudes and Urban Planning Servitudes}

According to the provisions of art. 755 of the New Romanian Civil Code, servitude is "the grant of a non-possessory property interest that grants the servitude holder permission to use another person's land". Any servitude usually involves two pieces of land belonging to different owners, where one serves as the servient estate that "bears the burden" and the other is the dominant estate, which benefits from the grant of the servitude and has permission to use the servient land in some manner. However, there may be cases when the servitudes are reciprocal. According to art. 755 par. (2) of the New Romanian Civil Code, by the grant of the servitude, the dominant estate may increase its economic value or comfort.

As a novelty, the New Romanian Civil Code restricts the servitudes' category to conventional servitudes, whereas natural and legal servitudes become legal private property right limits, distinctively regulated by the provisions of art. 555 of the New Romanian Civil Code. This law amendment is the result of constant criticism coming from legal advisors who, relying on the classification provided by the 1865 Civil Code, showed that neither natural nor legal servitudes are dismemberments ("dezmembrăminte") of the property right related to the servient estate, but they are merely limitations of the property right ${ }^{1}$. As a rule, while preserving some of

\footnotetext{
1 Alexandru- Sorin Ciobanu, Aspecte specifice privind regimul domeniului public în România şi în Franţa, "Universul Juridic" Publishing House, Bucharest, 2012, p. 107.
} 
the provisions of the former Civil Code, the Law no. 287/2009 implementing the New Romanian Civil Code stipulates that the exercise of the property right may be legally limited for either private or public interests reasons ${ }^{2}$.

These property right limitations are referred to in the new provisions regulating water use (natural course ${ }^{3}$ or artificial course $e^{4}$, irrigation costs, the obligation of the owner having too much water for their current needs to offer the surplus to another owner who could only purchase this resource at very high prices), gutter drops, distance and regimen of intermediate works required for certain buildings, works and plantations (minimum distance in construction works), the right to have a view of the neighbour's property (the regimen of the window or opening in the common wall ${ }^{5}$, minimum distance for the view window, the regimen of the light window ${ }^{6}$ ), the right of passage (the former right-of-way servitude for the owner of the estate with no direct access to public road).

The right of passage is accessory to the estate, from which it may not be separated to form an independent right. Therefore, the changing of the holder of the property right over the land which makes up the servient estate is legally irrelevant, since the right of passage endures as long as the situation that created it exists ${ }^{7}$. Art. 617 par. 1 of the Romanian Civil Code dwells on the absolute impossibility of access to the public road of the person asking for a right of passage on the land belonging to another person. The text refers to the case in which the owner of the dominant estate has no access to the public road.

On the other hand, urban planning rules define the prescriptions the observance of which is compulsory for all natural persons or corporate bodies using urban areas in one way or another.

Pursuant to art. 10 of the Law no. 350/2001 on land development and urban planning, the main goal of the latter is "to stimulate the complex evolution of localities by creating short-, medium- and long-term development strategies".

The urban planning rule limits the property right, especially the property owners' prerogatives related to the management of their assets. Thus, the encumbrance that they generate is called urban planning servitude. The name is not perfect if we consider that, in classical theory, a servitude is a burden upon a piece of property for the benefit of another, in other words, the charge placed upon a "servient estate" for the benefit of a "dominant estate".

Urban planning servitudes (rules) are administrative restrictions applied to the property right, with a view to serving public interest, namely urban development. Thus, servitudes play an essential role in defining the concept of "urban renewal".

Specialists have long ago accepted the existence of the so-called urban servitudes, "i.e. measures taken by various laws and regulations the purpose of which is the embellishment of and hygienic conditions in cities and towns, related to the alignment of houses, height of buildings and number of storeys, to building erection, repairs or demolishing, to sewage works, etc., requirements that all owners must abide by."

Based on the extent criterion, urban planning rules may be classified in: general, local and special rules. General urban planning rules are set by a country's central government and they are generally valid throughout that country, as they provide land use planning prescriptions

\footnotetext{
${ }^{2}$ See art. 602 par. 1 of the New Romanian Civil Code, republished.

${ }^{3}$ Art. 604 of the New Romanian Civil Code.

${ }^{4}$ Art. 605 of the New Romanian Civil Code.

${ }^{5}$ According to art. 614 of the New Romanian Civil Code, "No window or opening in the common wall may be done except with the owners' agreement".

${ }^{6}$ According to art. 616 of the New Romanian Civil Code, "The provisions of art. 615 do not forbid an owner from opening light windows with no distance limitations if these windows have no view of the neighbouring tenement".

${ }^{7}$ Gabriel Boroi, Liviu Stănciulescu, Instituţii de drept civil în reglementarea Noului cod civil, "Hamangiu" Publishing House, Bucharest, 2012, p.26.

${ }^{8}$ Mircea Duţu, Dreptul urbanismului, $5^{\text {th }}$ revised and enlarged edition, "Universul Juridic" Publishing House, Bucharest, 2010, p. 160.

${ }^{9}$ C. Hamangiu, I. Rosetti- Bălănescu, Al. Băicoianu, Tratat de drept civil român, vol. II, ALL Publishing, Bucharest, 1998, p.31, quoted in Mircea Duţu, op. cit., p. 161.
} 


\section{S. E. Ciudin - Colţa}

and rules restricting the building right. Local rules allow adapting urban planning requirements to the concrete needs of each region, and they are included in local urban planning regulations passed by local councils. As concerns special urban planning rules, they only apply to particular cases, with a well-defined object, such as, for instance, the protection and preservation of urban sectors with special historical-architectural value.

Note that both private servitudes and urban planning servitudes are indivisible real rights involving the whole property, regardless of its form of ownership ${ }^{10}$. The two types of servitudes also share the following similarities ${ }^{11}$ : they limit the attributes of the property right over a piece of immovable property; both categories encumber the property and not the owner, which means that the servitude outlives the owner; both categories of servitudes are placed upon property through its nature and not upon property through its destination; they are accessories to the property they encumber and have no independent life, which means that they are transmitted with the servient estate.

The elements that distinguish ${ }^{12}$ private servitudes from urban planning servitudes result from the fact that, whereas the later are, by their nature, administrative restrictions, enforced to promote public interest, related to a rational management of urban areas, the former originate in two properties neighbouring each other, which leads to a state of things that is the source of a series of obligations of one of the owners to the other and of certain restrictions of the right of each of them.

Whereas in private law servitudes may be generated by the parties' will ${ }^{13}$, in urban planning law they occur as a result of the lawmaker's or another official's will. Also, whereas the holder of the servient estate is bound only by the obligation not to act, urban planning servitudes also grant the holder prerogatives related to their obligation to act. Another distinction ${ }^{14}$ between private servitudes and urban planning servitudes is the fact that the former require the existence of two neighbouring estates with different owners, i.e. a dominant estate and a servient one, which is not the case with urban planning servitudes. Urban planning servitude may be altered or changed in relation to the legislative act that expresses it, more precisely depending on the lawmaker's intention in connection with the public interest that it satisfies. This does not prevent some servitudes from having a virtually permanent nature. However, most of them are temporary. On the other hand, civil servitude is perpetual, which means that the servitude will endure as long as the two properties exist and as long as the situation that generated the servitude requires it.

The New Romanian Civil Code allows (under the reserve of their compatibility) the burdening of the exercise of the public property right with any and all limitations acknowledged for the private property right. This category includes the former natural and legal pseudoservitudes regulated by the Civil Code of 1865 .

It is important to note the extension of the analyzed principle to include the private goods in the public domain, a good example being cultural heritage assets ${ }^{15}$. It has been shown that the servitude burdening interdiction also applies to such assets, for the purpose of achieving adequate protection and preservation; however, servitudes that are compatible with these assets and that have been dully constituted are acceptable ${ }^{16}$.

Servitudes that are compatible with public use or interest may be placed upon assets which, by their nature, are in general use or upon public interest assets that community profits from indirectly (like schools, hospitals, museums, etc. $)^{17}$.

\footnotetext{
${ }^{10}$ Mircea Duţu, op.cit., p.162.

${ }^{11}$ Idem.

${ }^{12}$ Idem.

${ }^{13}$ Viorel Terzea, Servituţile în dreptul civil român, "C.H. Beck” Publishing House, Bucharest, 2006, p. 9.

${ }^{14}$ Mircea Duţu, op.cit., p. 163.

${ }^{15}$ Alexandru- Sorin Ciobanu, op.cit., p.156.

${ }_{17}^{16}$ Alexandru- Sorin Ciobanu, op. cit., p.156.

17 Idem.
} 
Pursuant to the law, although the servitudes (in the general terminology of the Law no. 213/1998 regulating public property) or the legal limitations (which the New Romanian Civil Code refers to) arose before that piece of property was transferred into the public domain, if the said compatibility does not exist, they will cease to exist automatically, with theoretically no other decision required. In practice, however, an administrative decision is required which acknowledges the state of things and resolves all doubts that may exist. This administrative instrument may be challenged by the concerned and injured party (the beneficiary of the servitude) and sent for settlement by a court of law. Based on this decision, officials may even order the removal ex officio of any facilities, signs, etc. that servitude exercise relied on ${ }^{18}$.

The Law no. 350/2001 regulating land use planning and urban planning has general provisions concerning urban planning servitudes, leasing the task of their detailed presentation to the various technical and administrative regulations. The diversification of public utilities and works, of public utility facilities and networks has inevitably led to the need of enforcement of such public domain appurtenances protection instruments.

Nevertheless, the exercise of these special rights is not solely at the discretion of the officials. In most cases, an agreement concluded with the owner or the user of the impaired private property tenement or, failing agreement, a court decision is required. At the same time, one should note that in our legislative system, the exercise of the rights referred to above is usually done for a fee and requires that private owners be indemnified for the damages suffered ${ }^{19}$.

\section{“Urban Renewal” Defined by the Wallonian Code on Land Use Planning, Urban Planning, Patrimony and Energy}

Community is defined ${ }^{20}$ as an enduring social structure, which includes a relatively small number of individuals with similar cultural grounds and social statuses, who live in a relatively big area and who enjoy viable relations of cooperation, which allows the exercise of efficient social control in that group.

Considering the assumption according to which the notion of community development is equivalent to the whole set of mechanisms employed to produce collective welfare, as this latter concept was grounded in market economy-based societies, one may rightfully ask oneself the following question: is collective welfare the result of an individual effort or, on the contrary, the product of joint efforts? If we adhere to the solidarity thesis, do we accept that, in order to prove their efficiency, such efforts should be analyzed at the level of local communities, narrow communities or, on the contrary, of the society?

Community development strategy innovation and efficiency depend on the use of unexplored resources: community and community effort ${ }^{21}$.

The object of community development programs is community members' mentality changing, awareness raising and technical skills training, with a view to enhancing community prosperity.

Being closely connected to a local community's efforts, the concept of "urban renewal" is a natural and spontaneous phenomenon by means of which cities evolve. However, during this process, the natural evolution of a city may have to overcome various obstacles or it may be overwhelmed with the much too quickly changing nature of human activities. If this is the case, the disequilibrium may only be corrected by systemic planning measures ${ }^{22}$.

\footnotetext{
18 Ibidem, p. 157.

19 Ibidem, p. 136.

${ }^{20}$ Maria Bulgaru, Sociologie. Vol II, Chişinău, 2003, document available online at the following address http://tempus2010.usm.md/ManualePDF/Sociologie\%202.pdf, accessed on 20 September 2014.

${ }^{21}$ Idem.

${ }^{22}$ André Poissonnier, La rénovation urbaine, Éditions Beger- Levrault, 5 Rue Auguste-Comte, Paris, 1965, p. 19.
} 


\section{S. E. Ciudin - Colţa}

The society we live in seems to be a reaction, a response to a delayed progress, which is mostly visible in our habitat ${ }^{23}$. Whole families live in abandoned houses in remote neighbourhoods on the outskirts of cities.

Therefore, "urban renewal" is a far-reaching action designed to modernize certain areas or whole neighbourhoods and also an action striving to restore the structure and architectural form "worthy of our times" 24 of city centres uncared for, with abandoned buildings. Renewal operations therefore have both social implications, as they occur as a response to the problems that communities have to face, and an urban planning component, which includes several steps: purchasing the properties that will be renewed, their depopulation by the relocation of their occupants, building demolishing and land management and planning.

The first paragraph of art. 173 of the Wallonian Code on land use planning, urban planning, patrimony and energy ${ }^{25}$ defines the concept of "urban renewal" as an action of global and concerted planning initiated by the city, the purpose of which is the restructuring, cleaning or rehabilitation of an urban perimeter in order to support local population conservation or development, while at the same time promoting its social, economic and cultural function, and respecting the cultural and architectural characteristics of the area.

According to these provisions, the urban renewal operation aims at habitat conservation and improvement by one or several of the following actions: dwelling rehabilitation or building; green area creation or improvement; business and service provision building erection or improvement; creation or improvement of public facilities, as they were defined by the Government.

Note also that art. 172 of the same Wallonian Code defines the concept of "urban revival" ${ }^{26}$ as the action that is designed, inside a well-defined perimeter, to improve and develop the habitat from the viewpoint of its commercial functions. This action actually consists of the implementation of various agreements the main actors of which are the private sector and the administrative territorial unit. When the city and one or several private natural persons or corporate bodies conclude an agreement related to an urban revival operation, the Region may grant the city a subsidy covering up to $100 \%$ of the total costs, if the operation has to do with public domain planning and development consisting of road equipment, public lighting and sewage systems, green area development, urban planning of public areas.

Such planning and development actions are focused on an urban revival perimeter set by the Government, on the proposition of the Local Council. The public works which the urban revival operation consists of must comply with the provisions of the Regional Regulations on Buildings applicable to areas protected by certain administrative and territorial units ("zones protégées de certaines communes"27), from an urban planning point of view.

Pursuant to paragraph 4 of the same article 172, any agreement concluded by the city with private natural persons or corporate bodies referred to above must observe the principle according to which, for each franc granted by the Region, private natural persons or corporate bodies must invest at least two francs in at least one of the following activities ${ }^{28}$ : transformation and improvement of insalubrious dwellings that may be reconditioned; demolishing of insalubrious dwellings and building new ones; turning various buildings into dwellings; building dwellings.

We may therefore conclude that, despite the similarities between "urban revival" and "urban renewal" from the point of view of the goals of each local community, the difference lies in the specific activities encompassed by each concept and in their social, economic and cultural

\footnotetext{
${ }^{23}$ Idem.

${ }^{24}$ This expression belongs to the Minister of Construction of France in 1959, quoted by André Poissonnier in $L a$ rénovation urbaine, Éditions Beger- Levrault, 5 Rue Auguste-Comte, Paris, 1965, p. 20.

${ }^{25}$ Michel Delnoy, CWATUPE- Le Code Wallon de l'Aménagement du Territoire, de l'Urbanisme, du Patrimoine et de l'Energie, Editeur responsable L. Venanzi Edi.pro, Liège, Belgique, 2010, p. 136.

${ }^{26}$ Ibidem, p. 135.

${ }^{27}$ Idem.

${ }^{28}$ Idem.
} 
functions, which are more significant in urban renewal. Therefore, although urban revival consists of improving and developing the urban environment by public-private partnerships, in addition to the rehabilitation operations, urban renewal also includes the restructuring, cleaning and creation of a new urban perimeter. In this latter case, local initiative plays the most important role ("initiative communale" 29 ).

When most of the buildings that need renewal have private owners and private initiative often proves insufficient, it is the lawmaker's duty to authorize officials to enforce various measures meant to rehabilitate these lands.

Thus, notwithstanding private law provisions governing land ownership, renewal operations include all the legal proceedings that allow private assets to be assigned to a public use. The legal actions taken to carry out urban renewal should consider preserving this fine balance between public and private ownership law.

\section{"Urban Renewal" in the Light of the French Legislation}

Being urged by the need to have the cities in the northern and eastern areas of the country rebuilt, the Parliament passed the Cornudet Law on 14 March 1919 that was the first law regulating urban planning, named after the reporter's name ${ }^{30}$.

According to this law, towns and cities with more than 10,000 inhabitants had the obligation to conceive town planning, embellishment and enlargement projects within a deadline of 3 years. These projects also involved green areas, easements and types of buildings adapted to the area where they were erected. The Law of 1924, which was the second urban planning law, regulated the parcelling procedure. Based on an official layout plan and on a set of technical specifications, the mayor was authorized to hold back land that would be used for green areas, new buildings or public utilities.

At the same time, the Urban Planning Law of 15 June 1943 brought to the public's attention the notion of "urban regrouping" applying to "intercommunal" ${ }_{1}$ project, like plans including several localities. The legal provisions emphasized two important principles meant to facilitate the creation of these official layout plans, namely the "principle of public interest" and the "principle of non indemnification of urban planning servitude effects", which servitudes derived from these very plans.

In France, the Decree no. 560 of 20 May 1955 on the simplification of urban planning operations and on the support of "city islands" to the detriment of the suburbs abolished the special rules allowing expropriation for unsanitary conditions, and the expropriations required for "city island" improvement and planning began to be regulated by common law provisions. In fact, the Degree above is the first legal provision using the expression "city island renewal".

In case of large industrial and business areas as the ones around Lyon or Lille- RoubaixTourcoing- Armentières, it is imperative to pass a unique renewal policy for each of them, and that this initiative be passed on to a local body able to group together the concerned communities $^{32}$. In order to fulfil their mission, local communities are authorized to resell the land on which any inadequate buildings were demolished to contractors willing and able to build new neighbourhoods on it.

In France ${ }^{33}$, the provisions of the Law no. 683 of 6 August 1953 first authorized the central and local governments, as well as any qualified public bodies, to expropriate open and even built-on land in order to support the erection of new buildings or to satisfy the need of

\footnotetext{
${ }^{29}$ Michel Delnoy, op.cit., p. 136.

${ }^{30}$ Oliviu Puie, Reglementări juridice în materia urbanismului. Dreptul de proprietate şi contenciosul administrativ în materie, "Universul Juridic" Publishing House, Bucharest, 2011, p. 6.

${ }^{31}$ Ibidem, p. 7

32 Ibidem, p. 32.

${ }^{33}$ Oliviu Puie, op. cit., p. 36.
} 


\section{S. E. Ciudin - Colţa}

planning and development of the areas included in official layout plans provided for in the abovementioned law.

This text was later amended and finally abolished by the provisions of the Ordinance no. 997 of 23 October 1958 on the consolidation of the expropriation procedure, pursuant to which the land resulted from expropriations for public interest purposes was assigned to various contractors provided they used it according to the technical specifications enclosed to the assignment contracts ${ }^{34}$. Thus, the only requirement that had to be met was that the operation be declared of public interest, "as the renewal operations are of public interest just as erecting building complexes is of public interest" ${ }^{35}$.

Starting with the 1970's, one may note a certain evolution of the legal environmental protection provisions, the effects of which extended and covered the manner in which private property was protected. The Law on urban solidarity and renewal (also called the SRU Law), passed on 13 December 2000, provided better coordination between urban planning policies and space division policies, considering the concept of sustainable development. The law had three components: an urban planning component that referred to the tax reform in the field, a habitat component focusing on the solidarity between cities with an emphasis on the social implications of urbanized areas and, last but not least, an "urban displacement" component related to transportation in large urbanized areas.

\section{The Principle of Non Indemnification of Urban Planning Servitude Effects}

Special doctrinary and legislative attention is currently paid in Romania to urban planning conduct.

Urban planning rules come to limit the private property right and the prerogatives of the owners related to the manner in which they manage their own assets. The encumbrances originating here are called "urban planning servitudes", as they are considered to satisfy public interest, as rational urban planning and management ${ }^{36}$.

Their purpose is to ensure the harmonious layout of buildings erected in an urban environment or to more or less assign to these buildings other forms of urban soil uses designed to prevent serious malfunctions: spills, natural environment destruction, and uncontrollable rise of equipment needs.

Whereas urban planning rules are concerned with the actual disposition of buildings in space, with their volume, or exterior aspect, general building regulations that contractors have to comply with, which are separate from urban panning regulations, are concerned with interior volume, noise insulation, protection against leaks, material strength, in short with the very building to erect, and not with space planning ${ }^{37}$.

Urban planning servitudes are governed by the principle of non indemnification of their effects. Servitudes may directly influence the right to erect buildings (non aedificandi servitudes, concerned with building density and height), the manner of erecting buildings (like the ones derived from the architectural prescriptions of urban plans) or, in a more general manner, the possibility to use the land.

Continental law, and more specifically French law, established the principle of non indemnification of urban planning servitude effects as early as the first half of the $19^{\text {th }}$ century, which principle was also imported by Romanian law. The arguments of its establishment are, on the one hand, the fact that urban planning, as a general interest activity, imposes such inconveniences on people and, on the other hand, the fact that indemnifying this type of easements would generate a financial burden and a fast, excessive and unbearable price increase

\footnotetext{
${ }^{34}$ André Poissonnier, op. cit, p. 36.

${ }^{35}$ Ibidem, p. 24.

${ }^{36}$ Alexandru- Sorin Ciobanu, op. cit., p. 160.

${ }^{37}$ Mircea Duţu, op. cit., p. 166.
} 
for the public budget, which would impede on urban planning policies thus leading to serious problems $^{38}$.

Thus, it is stipulated that private owners cannot claim any compensation for the damage arising from and related to an urban planning servitude, except when there is proof of the officials' illegal behaviour.

The case law of the Constitutional Court of Romania states that "... land owners are entitled to compensations if they are prevented from using their land, which is used for green areas and/or provided as such in urban planning documents". Thus, "nothing prevents an individual having suffered damages as a result of their legal interdiction from claiming compensations for these damages from the local government officials, in accordance with the common law" ${ }^{39}$, which means transferring the case into the realm of tort liability, with the consequences associated with it.

A principle accepted in some western countries, such as France, but not in Romania, is the principle of independence of legislations, in the sense that urban planning rules remain parallel to the other regulations influencing soil use. This also means that, unless otherwise provided by a law, any licence or permit granted under a particular regulation does not also grant authorization in another field, even when they are similar ${ }^{40}$.

\section{Conclusions}

Although the urban renewal process seems to be a national imperative mobilizing public power energies, each operation bears a local interest ${ }^{41}$. Harmonizing public interests, based on which building and urban planning officials intervene, with private interests, when the need arises to protect private property rights, is currently a challenge for both lawmakers and officials authorized to implement and enforce legal provisions. Therefore, the use of coercion means made available to public officials by lawmakers may seriously prejudice private property rights, by depriving owners of their right to freely dispose of their own assets. Consequently, in our opinion, in order to find the answer to the question whether common welfare is the result of individual or common efforts, and in order to be able to implement, in Romania, an urban renewal initiative, which may have implications on the whole local community and subsequently on the whole society, it is necessary that at least the identification of the problems that a community faces and the finding of the best solution be the fruit of individual efforts. Their subsequent implementation should be then left to competent official bodies, if this is too great a task to be solved by individual effort.

\section{Bibliography}

- A.- S. Ciobanu, Aspecte specifice privind regimul domeniului public în România şi în Franţa, "Universul Juridic" Publishing House, Bucharest, 2012;

- G. Boroi, Liviu Stănciulescu, Instituţii de drept civil în reglementarea Noului cod civil, "Hamangiu" Publishing House, Bucharest, 2012;

- Puie, Reglementări juridice în materia urbanismului. Dreptul de proprietate şi contenciosul administrativ în materie, "Universul Juridic" Publishing House, Bucharest, 2011;

- Noul Cod Civil şi 9 legi uzuale, "Hamangiu” Publishing House, Bucharest, 2011;

- M. Delnoy, CWATUPE- Le Code Wallon de l'Aménagement du Territoire, de l'Urbanisme, du Patrimoine et de l'Energie, Editeur responsable L. Venanzi Edi. pro, Liège, Belgique, 2010;

- M. Duţu, Dreptul urbanismului, $5^{\text {th }}$ revised and enlarged edition, "Universul Juridic" Publishing House, Bucharest, 2010;

\footnotetext{
${ }^{38}$ Mircea Duţu, op. cit., p. 166.

${ }^{39}$ Ibidem, p. 167.

${ }^{40}$ Idem.

${ }^{41}$ André Poissonnier, op. cit, p. 31.
} 


\section{S. E. Ciudin - Colţa}

- V. Terzea, Servituţile în dreptul civil român, "C.H. Beck" Publishing House, Bucharest, 2006;

- Maria Bulgaru, Sociologie. Vol II, Chişinău, 2003, document available online at the following address http://tempus2010.usm.md/ManualePDF/Sociologie\%202.pdf, accessed on 20 September 2014;

- André Poissonnier, La rénovation urbaine, Éditions Beger- Levrault, 5 Rue Auguste-Comte, Paris, 1965.

- This work was supported by the strategic grant POSDRU/159/1.5/S/141699, Project ID 141699, co-financed by the European Social Fund within the Sectorial Operational Program Human Resources Development 2007- 2013. 